\begin{tabular}{lcr}
\hline \multicolumn{1}{c}{ A N N A L E S } \\
UNIVERSitatis & MARIAE CURIE-SKŁODOWSKA \\
LUBLIN - POLONIA & 2020 \\
\hline
\end{tabular}

Maria Curie-Skłodowska University. Institute of Political Science and Administration

\author{
AGNIESZKA ELŻBIETA DEMCZUK
}

ORCID ID: https://orcid.org/0000-0003-2691-2043

\title{
The Discriminatory Legalism Strategy and Hate Speech Cases in Poland. The Role of the Commissioner for Human Rights in Fighting Discrimination
}

\begin{abstract}
The regress of liberal democracy in the world has been progressing for years and the number of countries with the full democracy index is decreasing [Economist Intelligence Unit 2018, 2019; Freedom House 2018]. One of the serious threats to the rule of law and the human rights in modern democracy has become discriminatory legalism which is both strategy and weapon [Weyland 2013]. In order to weaken or marginalize the opposition and "rebellious" citizens, public authorities apply discriminatory legal instruments and democratic rules depending on who they are concerned with. Public authorities do this because of political views and use exclusion rhetoric, a language of hatred, stigmatizing all "strangers", at last use hate speech on the Internet and beyond. The weaponization of hate speech is a convenient instrument for political struggle and the fight against inconvenient opponents. Hate speech is also used by far-right and nationalist organizations in the public sphere, which operate in an atmosphere of consent to their radical behaviour. Political hate speech plays an important role in the discriminatory legal strategy. Poland is included in the group of countries with flawed democracy (Article 7(1) TEU since 2017). The authorities introduced changes in law (which were defined as the "Frankensteinisation of legislation" by the Parliamentary Assembly of Council of Europe [PACE] in 2019), democratic institutions and the prosecution applies a discriminatory legalism strategy. This problem is highlighted by the current Commissioner for Human Rights which is an independent institution in the field of fighting hate speech (except a few independent media and NGOs informing about the hate speech phenomenon). Many of hate speech cases are discontinued or not taken up by the prosecution. The numbers of cases of hate speech and hate incidents are increasing but the Polish authorities use the underreporting mechanism. The Ombudsman warns that only $5 \%$ of cases are reported to the police. The language of hatred and contempt used by the authorities in Poland has become the weaponization in the fight against citizens as political opponents: LGBT+ community, refugees, political opponents, independent judges and others.
\end{abstract}

Key words: Poland, discriminatory legalism, populism, hate speech, Commissioner for Human Rights, rule of law 


\section{INTRODUCTION}

A dramatic change occurred in Polish constitutional politics in October 2015: a combined presidential and parliamentary victory of the populist Law and Justice party (PiS) began a series of deep political and legal changes which turned the constitutional order on its head in many respects. The end of the year 2015 witnessed the beginning of a fundamental transformation: abandonment of various dogmas of liberal democracy, constitutionalism and the rule of law, which so far had been taken for granted. The campaign, first against the Constitutional Tribunal (CT) and then against the regular courts, rested upon the idea that any restraints upon the political majority are by their nature antidemocratic [Sadurski 2018: 1].

The political, social and legal situation has changed dramatically. The Parliament adopted many amendments against the concept of the democratic state of law in 2015-2020. ${ }^{1}$ As a result of these developments, Poland, once a paradigm of a successful transition into democracy in the 1990s, has become a pariah of the European Union [Matczak 2019: 407].

According to the Economist Intelligence Unit [2020], the ruling ${ }^{2}$ Law and Justice party, which won the October 2019 parliamentary election again, will continue to implement controversial, nationalist policies. Its failure to address the rule of law issues may prompt the EU to try to impose sanctions on Poland. The ongoing crisis of liberal democracy in Poland and the failure to promote, protect and enforce the rule of law, the human rights and non-discrimination have more universal and deep-seated causes. This crisis is not endemic to Poland because liberal democracy is in crisis everywhere. ${ }^{3}$ According to the 2019 Democracy Index, 76 of the 167 countries ( $45.5 \%$ of all countries) can be considered to be democracies. The number of "full

1 The Parliament adopted the following amendments, e.g. the Civil Service Law in 2015 (higher civil service positions are filled by appointment rather than competition), the Public Prosecutor General Law in 2016 (the position of independent Public Prosecutor General was combined with the Ministry of Justice), the Surveillance Law in 2015 (the law opens the possibility of uncontrolled downloading Internet data by the police and special services), eight amendments to the Supreme Court in 2016-2019, the amendments to the Law on the Common Courts, the Law on the Supreme Court and Some Other Laws (known as "muzzle law") in 2019 (the amendments diminish judicial independence and put Polish judges into the situation of having to face disciplinary proceedings for decisions required by the ECHR, the law of the European Union, and other international instruments), the Assembly Law in 2016 (the amendments introduced controversial provisions on cyclical assemblies which are criticized [e.g. Amnesty International, the Helsinki Foundation for Human Rights], regulations are unclear, favor one type of assembly, the decisions about an organization of the demonstrations that should be taken locally are in the hands of government administration) [see more: Everything...].

2 The Polish government is co-created by: Law and Justice (Pol.: Prawo i Sprawiedliwość), a conservative-nationalist party, leading the informal United Right (Pol.: Zjednoczona Prawica) governing coalition, Agreement (Pol.: Porozumienie) a conservative-liberal party and United Poland (Pol.: Solidarna Polska) a conservative-nationalist party.

3 According to The Economist Intelligence Unit's measure of democracy, almost one-half (48.4\%) of the world's population live in a democracy of some sort, although only $5.7 \%$ reside in a "full democracy", down from $8.9 \%$ in 2015 as a result of the US being demoted from a "full democracy" to a "flawed 
democracies" increased to 22 in 2019, up from 20 in 2018. The number of "flawed democracies" fell by one to 54 in 2019 [European Democracy Index 2019: 3]. And a wave of populism is sweeping across the advanced democracies in the northern hemisphere. Though in different forms and to different degrees, populism has begun to shape the political life of established democracies including the United States, the United Kingdom, France, Germany, Austria, the Netherlands, Sweden, Greece, Italy, as well as, perhaps most spectacularly in Europe, the more recent democracies of Hungary and Poland [Lacey 2019: 4]. Right-wing populist parties are currently growing more rapidly than ever before and have increased their voter support with 33\% in four years [Timbro Authoritarian Populism Index 2019: 4].

One of the manifestations of populist policy is the use of the strategy of discriminatory legalism which is also a weapon in the fight against political opponents but can also serve to create the myth of a homogeneous sovereign. The discriminatory legalism is used to colonize civil society, silence critical voices in the public sphere, and harass the opposition [de la Torre 2017: 1275]. When the institutions such as the judiciary are taken over or co-opted by populists, a situation arises, called by some scholars forms of "abusive constitutionalism" or "discriminatory" or "autocratic legalism" [Müller 2017], in which the law itself is used to persecute minorities, to punish dissent, and to enforce executive power discursively legitimized by the will of the people [Lacey 2019: 14].

The Polish populist government and the United Right politicians supported by, e.g. the Catholic Church, the selected organizations, the public media and the selected right-wing media that have become the beneficiaries of "the good change" since the 2015 parliamentary election use the exclusive, stigmatizing and hateful language against all the "strangers" and "others" who are political opponents of the ruling party. The term "good change" means the deep changes in almost every area of public life in Poland due to the national and conservative spirit. The LGBT community, refugees, Ukrainians, judges, protesting doctors, teachers, and NGOs leaders have become victims of hate speech in Poland. The phenomenon of hate speech is widely present in cyberspace, especially in the social media, the public media and in many political statements. And the atmosphere of consent is observed in the public sphere. The goal of this article is to present the scale and extent of the hate speech phenomenon used as an instrument or the weapon of the discriminatory legalism strategy on the example of LGBT community and refugees, lack of action on the part of the authorities, as well as to present the role of the Commissioner for Human Rights in its fight against hate speech in Poland. Unfortunately, the Polish Ombudsman is the isolated authority that undertakes the actions in Poland to combat hate speech and to implement relevant education to counteract it. Almost every single independent institution in Poland is appropriated by the ruling party and its

democracy" in 2016. More than one-third of the world's population live under authoritarian rule, with a large share being in China [EIU, Democracy Index 2019: 3]. 
supporters, beneficiaries of the "good change". The Commissioner is appointed by the Sejm and approved by the Senate for a 5-year term. The current Ombudsman's term ends in 2020 .

\section{METHODOLOGY}

The author used system analysis, decision-making, comparative, quantitative behavioural and empirical methods. The analysis was conducted on the basis of reports of NGOs (e.g. the Helsinki Foundation for Human Rights, the European Front $^{4}$ ), think tanks (e.g. the Stefan Batory Foundation, The Economist Intelligence Unit, Freedom House) and opinion polling centres (e.g. the Polish Public Opinion Research Centre). Legal documents, judicial, legal opinion and judgments regarding freedom of expression and hate speech (Venice Commission of the Council of Europe, European Courts of Human Rights, official statements of public institutes and authorities) were also examined. The author used the desk research method which is based on public documents, statistics, analysis reports and publications whose examination helps to develop a diagnosis of the scale of hate speech in Poland and the measures taken to prevent or combat this phenomenon. As part of the quantitative method, the author has analysed the statistical data of the Central Statistical Office. The analysis of the scale, dynamics and content of hate speech and fake news was made on the basis of observation of social behaviour based on the social listening method. This method is a quantitative and qualitative study of hate speech cases published in cyberspace. The streaming method is used to analyse the frequency of occurrence of computational propaganda in cyberspace. This method is relatively new in the field of computer science and extremely helpful for analysing the scale, dynamics, scope and content of public discourse on a selected topic. The author conducted an analysis on the basis of three reports of two NGOs - the Helsinki Foundation for Human Rights and the European Front.

\section{RULE OF LAW AND HUMAN RIGHTS AS FUNDAMENTAL PRINCIPLES OF THE LIBERAL DEMOCRACIES IN THE EUROPEAN UNION}

The concept of a democratic state of law principle is fulfilled by a combination of the formal and the material elements [Dziemidok-Olszewska, Sokół 2012: 351-352]. The democratic rule of law is a state in which the law reflects the accepted value system, based on natural law and standards of international law. And what is especially important in the democratic state of law, the will of the majority (expressed

4 The European Front is an informal initiative jointly created by pro-European non-governmental organizations, e.g. Prof. Bronisław Geremek Foundation, Robert Schuman Foundation. 
in the form of an act), must, however, be consistent with constitutional law and may be overcome by the constitutional court. In other words, that role is fulfilled by the constitutional court and courts. Article 2 of the Constitution of the Republic of Poland of 2 April 1997 ensures the principle of a democratic state of law: "The Republic of Poland shall be a democratic state ruled by law and implementing the principles of social justice". The principle since its establishment has had a very important influence on the process of political transformation in Poland after 1989 throughout the transitional period until the adoption of the Constitution in 1997. This happened in particular through a case law and an interpretation of the Constitutional Tribunal. It is the general principle of the political system as a standard to which the Constitutional Tribunal, as a result of the adoption of creative and dynamic interpretation of the system, described the basic catalogue of the necessary formal requirements and substantive. They constitute the "standard" democratic rule of law.

Article 2 of the Constitution contains the clause which had become the essential basis for the constitutionality of law and legal system in the period of political transformation in Poland. That rule of law framework and particular meta-rule are the catalogue of a number of other principles, each of which may be a spontaneous basis for assessing the constitutionality of acts. These principles are, e.g. citizens' trust in the state (the loyal behaviour towards the citizens), lex retro non agit, the principle of acquired rights, social justice, the respect for the common good, the stable and secure rights (good and appropriate legislation), the principle of separation of powers, the judicial independence, the right to a fair trial and the prohibition of excessive interference by the legislature in individual rights. The adopted formula of the democratic rule of law is both a frame for the activities of legislative, executive and judicial powers as well as a set of values in which the civil society the best develops. The rights of every member of civil society in the state of the rule of law should be protected and respected by every single public authority. No one may be discriminated against on the basis of political views, nationality, ethnicity, sexual orientation and other.

The rule of law is one of the common values upon which the European Union and part of the common constitutional traditions of all member states are founded. It is enshrined in Article 2 of the Treaty on European Union. The European Commission, together with all other EU institutions, is responsible under the Treaties for guaranteeing the rule of law as a fundamental value of our Union and making sure that EU law, values and principles are respected. Also, the rule of law means that all members of a society including governments and parliaments are equally subject to the law, under the control of independent courts, irrespective of political majorities. In the current constitutional crisis in Poland and the rule of law's crisis, the European Commission triggered the rule of law framework to address systemic threats in EU countries. It means that the European Commission has to trigger the mechanisms of Article 7 of the Treaty on European Union (TEU). This is done through dialogue with the EU country concerned. Unfortunately, for the first time in the history of 
the functioning of the European Union, the mechanism of Article 7 was triggered against Poland in 2017 ("the Case of Poland"). But as Nicola Lacey rightly points out, the Article 7 infringement procedure invoked against Hungary and Poland could lead to sanctions, but may be liable to feed the very populism which underlies the problem it seeks to address. In the international sphere, perhaps even more than in the national one, the robustness of norms of legality, such as human rights, is substantially dependent on voluntary compliance [Lacey 2019: 16-17]. However, it seems that the respect for the human rights, the principle of equality and the prohibition of the discrimination are not a priority for the Polish public authorities. Because the nation in the rhetoric of Law and Justice is a collective good, the good of the nation is interpreted as standing above the good of the individual, and the realization of the good of the nation becomes the realization of the good of the individual, its individual rights become subordinated to the rights of the nation.

Many changes in law regarding judiciary were justified as allegedly inspired by solutions already adopted in other EU countries. This tactic is called by the Council of Europe's Parliamentary Assembly ${ }^{5}$ as "Frankensteinisation of legislation". This is a process in which the Polish governing majority selects certain elements of judiciary systems in other countries and uses it to undermine the independence of the judiciary. It is based on a combination of "worst practises" existing in other countries, instead of on best practise and common European standards [Parliamentary Assembly 2019: 3]. But in fact, these amendments were to lead to the change in the mentioned paradigm in the relationship between the authority and the individual and the change of the priority of the good of the nation over the good of the individual.

The populist government in Poland maximizes its electoral chances and strives to secure public support by using the "mass clientism" instruments, as exemplified by numerous social transfers for the groups that can provide the electoral support, including the "Family 500+" programme, the thirteenth pension, "300+" (the "Good Start" programme), the electoral promise of the fourteenth pension in 2019. On the one hand, the government delivers the monthly benefit of PLN 500 to every family with two or more children (the key plank of 2015 Law and Justice campaign), then, in 2019, the programme has been extended to families with one child. But on the other hand, the government and Law and Justice politicians have systematically applied the strategy of discriminatory legalism to create a homogeneous sovereign myth for ad hoc political goals. Like any modern populist right-wing party, Law and Justice also uses a language that is discriminatory, stigmatizing, excluding, and full of contempt. This language used by populists is an essential element of discriminatory legalism which is both a strategy and weapon. But, it should be noticed that

5 In 2019, the PACE adopted a resolution concerning the functioning of democratic institutions in Poland. The adoption of the resolution ends 4-year proceedings focusing on rule of law developments in Poland, however, at the same time, the resolution opens a full monitoring procedure in respect of Poland (as well as of Turkey, Albania, or Georgia). 
discriminatory legalism violates human rights. First of all, it violates human dignity. Article 30 of the Polish Constitution states that: "The inherent and inalienable dignity of the person shall constitute a source of freedoms and rights of persons and citizens. It shall be inviolable. The respect and protection thereof shall be the obligation of public authorities". Thus, the authorities violate the Constitution of Poland by using discriminatory legalism.

\section{DISCRIMINATORY LEGALISM - STRATEGY AND WEAPON OF AUTHORITARIAN POPULISTS}

Jan-Werner Müller sees populism as a form of exclusionary identity politics which tends to undermine democracy and identifies three distinct manifestations of its logic: a kind of colonization of the state, mass clientelism as well as what political scientists sometimes call "discriminatory legalism", and, finally, the systematic repression of civil society [Müller 2016: 28]. The populist politician's claim to express the people's will does not brook any system of checks and balances such as that envisaged by modern constitutionalism, for the latter is premised on a pluralist view of politics. Moreover, the polarized and moralistic, friend/enemy, "pure us/ corrupt them" tenor of populism tends to erode the usual norms of civility [Lacey 2019: 13] and avoid, criticize and do not apply the rules of political correctness. Populist politicians have applied discriminatory legalism and its maxim "For my friends, everything; for my enemies, the law!" They take control of all major institutions including the courts, they have used formally legal authority in discretionary ways to promote their cronies and allies while punishing or intimidating critics and opponents in politics and society. With the government controlling all avenues of appeal and avoiding blatant violations of formal rules, those targeted find few chances for domestic recourse or the gathering of international support [Weyland 2013: 23]. For the rule of law not only constrains but enables governmental power, and populist governments need law as much as any other regime. Hence courts and other checking institutions need to be co-opted - as they may be by court-packing, intimidation of the judiciary or other mechanisms such as those which are recently observed in Poland and Hungary [Lacey 2019: 13-14].

Discriminatory legalism is the weapon used against anyone who does not share the point of view of populist politicians. It is an extra dangerous weapon especially in the era of omnipresent communication and information technologies, in particular social media. Social media are young, but they have already played a role in numerous turbulent protests and highly polarized elections in several countries. Social media have often been described as the site for the conflict between "good" democratic forces who use social media to make their voices heard and "bad" autocratic and repressive forces who aim to censor this channel to silence these liberal elements [Tucker et al. 2017: 47]. Freedom of information online and offline is an inherently democratic 
principle but social media are neither inherently democratic nor inherently undemocratic. Rather, social media constitute a space in which political interests battle for influence, and not all these interests are liberal or democratic [Tucker et al. 2017: 48].

Populist politicians use discriminatory legalism to control both the media, which play a public watchdog function in a democratic society, and independent organizations. Consequently, the space for civil society is gradually diminishing, among other things due to problems with access to free media including public media, as well as restrictions on financing of independent NGOs. The leaders of social movements, NGOs, and some economic, cultural elites and scientists are attacked as the enemies of the changes introduced by politicians using the strategy of discriminatory legalism. There can be observed the consequent process of the capture of state and independent democratic institutions, including the independent judges who are the guardians of the democratic civil liberties and the principle of non-discrimination.

\section{HATE SPEECH CASES AND THE “ATMOSPHERE OF CONSENT” IN POLAND}

In Europe's culturally diverse societies there is a need to reconcile the right to freedom of expression with other rights, such as freedom of belief, conscience or religion, which might sometimes compete with each other. It is a difficult challenge because these rights are at the core of democracy. Article 10 of the Convention for the Protection of Human Rights and Fundamental Freedom of 4 November 1950 (European Convention on Human Rights) states that: "Everyone has the right to freedom of expression, including freedom to hold opinions and to receive and impart information and ideas without interference by public authority and regardless of frontiers".

However, the Convention also provides that the exercise of these freedoms carries with it duties and responsibilities, and establishes that some limitations of these rights, including the protection of the reputation or rights of others, may in certain circumstances be possible. This regulation means that freedom of expression is not absolute and this freedom may be restricted, e.g. due to the need to guarantee the protection of human dignity. Hate speech, i.e. an offence of a racist, anti-Semitic, xenophobic, Islamophobic, homophobic, etc. nature must be banned because of the rights of persons who are members of a pluralist democratic society.

The European Court of Human Rights in Strasbourg stated that hate speech that may offend individuals or groups cannot claim any protection under Article 10. Of great significance is also Article 17 which prevents applicants from relying on the Convention on Human Rights (1950) in order to perform, promote and/or justify acts amounting to or characterized by, e.g. hatred, violence, xenophobia and racial discrimination, anti-Semitism, Islamophobia, terrorism and war crimes, negation and revision of clearly established historical facts, such as the Holocaust, contempt for victims of the Holocaust, of a war and/or of a totalitarian regime, totalitarian ideology and other political ideas incompatible with democracy. And when assess- 
ing an applicant's conduct and aims, in the light of Article 17, the European Court of Human Rights takes into account the values proclaimed and guaranteed by the European Convention, particularly as expressed in its Preamble as well as the values underlying the Convention such as: justice and peace, effective political democracy, peaceful settlement of international conflicts and sanctity of human life, tolerance, social peace and non-discrimination, gender equality and coexistence of members of society free from racial segregation ${ }^{6}$ [Guide on Article 17, 2019: 9-10]. Article 17 of the Convention calls for the so-called guillotine effect, i.e. the complaint is declared inadmissible and it is not examined in detail. The examination of the complaint under this Article is included in the procedure for examining the admissibility of a complaint before the European Court. This provision remains reserved for particularly drastic cases of abuse of rights and freedoms contained in the Convention, and such manifestations are most often taken to be anti-Semitism, racism and xenophobia.

As defined by the Committee of Ministers of the Council of Europe in 1997, hate speech shall be understood as covering all forms of expression which spread, incite, promote or justify racial hatred, xenophobia, anti-Semitism or other forms of hatred based on intolerance, including intolerance expressed by aggressive nationalism and ethnocentrism, discrimination and hostility against minorities, migrants and people of immigrant origin [Recommendation No. R (97) 20]. There is no universally agreed definition. Most countries have adopted legislations banning expressions that can be included in this concept, but with the slight differences as the important part of the militant democracy doctrine or democracy able to defend itself [Loewenstein 1937]. There are many regulations regarding hate speech in Poland, e.g. Article 13 of the Constitution of Poland (1997) and in particular three articles in the Criminal Code (1997). ${ }^{7}$

Pursuant to Article 13 of the Constitution of Poland, "political parties and other organizations whose programmes are based upon totalitarian methods and the modes of activity of Nazism, fascism and communism, as well as those whose programmes or activities sanction racial or national hatred, [...] shall be forbidden".

Article 119 of the Criminal Code states that: "Whoever uses violence or makes unlawful threat towards a group of persons or a particular individual because of their

6 See more the HUDOC database of the Court's case-law and, e.g. cases: Perinçek v. Switzerland [GC], $\S \S 115$ and 230; Kasymakhunov and Saybatalov v. Russia, § 106; Jersild v. Denmark, §35; Glimmerveen and Hagenbeek v. the Netherlands, Commission decision; Féret v. Belgium; W.P. and Others v. Poland; Norwood v. the United Kingdom (dec.); Seurot v. France (dec.); Leroy v. France, § 27; M'Bala M'Bala v. France (dec.); Garaudy v. France (dec.); Vajnai v. Hungary, § 25; Fáber v. Hungary, § 58; Vona v. Hungary, § 36; Vajnai v. Hungary, § 25; Refah Partisi (the Welfare Party) and Others v. Turkey [GC], § 132; German Communist Party (KPD) v. Germany, Commission decision and others [Guide on Article 17, 2019].

7 Yet Article 212.1 of the Penal Code states: "Whoever accuses another person, a group of persons, an institution, a legal person or an organisational unit having no legal personality of conduct or features which may humiliate them in public opinion or expose them to a loss of trust required in a given position, profession or type of activity, shall be punishable by a fine or restriction of personal freedom. Article 212.2 states: Whoever commits the offence specified in Article 212.1 by means of mass communication, shall be punishable by a fine, restriction of personal of liberty or term of imprisonment of up to one year". 
national, ethnic, political or religious affiliation, or because of their lack of religious beliefs, shall be subject to the penalty of the deprivation of liberty for a term of between 3 months and 5 years" $(\S 1)$. "The same punishment shall be imposed on anyone, who incites commission of the offence specified under $\S 1$ " ( $(2)$.

Article 256 of the Criminal Code states that: "Whoever publicly promotes a fascist or other totalitarian system of state or incites hatred based on national, ethnic, race or religious differences or for reason of lack of any religious denomination shall be subject to a fine, the penalty of restriction of liberty or the penalty of deprivation of liberty for up to 2 years" $(\S 1)$.

Article 257 of the Criminal Code states: "Whoever publicly insults a group within the population or a particular person because of his national, ethnic, race or religious affiliation or because of his lack of any religious denomination or for these reasons breaches the personal inviolability of another individual shall be subject to the penalty of deprivation of liberty for up to 3 years" $(\S 1)$.

Unfortunately, there is no prohibition of hate speech because of sexual orientation, disability, gender and others. Under the Polish law, it is possible to initiate civil causes of action in response to instances of hate speech under the provisions of the Civil Code. Article 23 provides protection to "the personal interests of a human being", including, inter alia, freedom and dignity. Under Article 24(1), aggrieved individuals can "demand that the action at issue ceases unless it is not unlawful"; or "demand that the person responsible for the infringement performs the necessary actions to negate its effects", in particular, to make "a declaration of the appropriate form and substance" (e.g. statement of apologize). They are also entitled to claim "monetary compensation or the payment of an appropriate amount of money to a specific public cause" or "to demand that the damage be remedied in accordance with general principles".

From 2015 to 2020, a considerable increase can be seen in the percentage of persons encountering hate speech in media and in everyday life. In 2016, the most common victims of hate speech were refugees ${ }^{8}$ and gay persons. According to the Centre for Research on Prejudice at the University of Warsaw, hate speech relatively often was disseminated against Muslims, Romani people and black persons. Hate speech is predominantly encountered by Poles on the Internet (in particular by youth), on TV (mainly adults) and in everyday interactions on the streets [Winiewski et al. 2016: 3]. According to the researchers from the Helsinki Foundation for Human Rights, a common feature of anti-immigrant, anti-Muslim, anti-refugee and

8 The refugee phenomenon concerns Poland to a much lesser extent than other EU member states, both in terms of the number of applications and people actually residing there. Between 2015 and 2018, Poles have changed from cautious supporters to decisive opponents of admitting refugees into the country [Łaciak, Segeš Frelak 2018: 9]. In the early stages of the refugee crisis, Poles were less sceptical than citizens of other countries in Central and Eastern Europe with 60\% opposed to admitting any refugees and $29 \%$ of those who agree to admit them temporarily into Poland [Public Opinion Research Centre, 2018: 1]. In 2018, there were 4,100 applications for international protection submitted in the Republic of Poland but the refugee status was granted to 406 foreigners [Office for Foreigners 2018]. 
anti-LGBT + community narratives was the presentation of these groups as a threat to social order, security, the culture and traditions of Poland and the Polish family [Mikulska-Jolles 2018: 33-34; 2020: 3]. But in 2019, the term "LGBT+" somewhat replaced the sinister figure of a refugee from 2015. Unlike refugees, however, the LGBT+ community is actually present in Poland.

From 2015 to 2020, there was (and still is) a smear campaign against the LGBT+ community, refugees, some judges, opposition politicians and other groups in Poland. The term "smear campaign" means "a planned attempt to harm the reputation of a person or company by telling lies about them" [Cambridge Dictionary]. For example, there were many pejorative metaphors and the hateful words addressed in the public debate towards the LGBT+ community (e.g. "decontamination after the LGBT+ march", "rainbow plague", "child sexualization by LGBT+", LGBT+ as a "homo-lobby", "homo-terror", "homo-propaganda", and "homo-revolution", the Pride March as "a promotion of perversions, deviations and denaturing"), ${ }^{9}$ towards the migrants (e.g. "demographic and social jihad", "refugees spread germs and disease", ${ }^{10}$ "every refugee is a terrorist", "refugees murder and rape women and children"), ${ }^{11}$ and towards the judges (e.g. "judges who are common thieves"). ${ }^{12}$ For example, in January 2020, President Andrzej Duda used the language referring to ethnic cleansing and pogroms: "We must cleanse our Polish home so that it would be clean, orderly, and beautiful". These metaphors give rise to negative and dangerous emotions and they evoke the worst associations of the past and gradually and systematically brutalize the public debate. They can encourage physical attacks on discredited people, which was the case, for example, in Białystok, Lublin, and Częstochowa during the 2019 Equality Marches.

In addition to hate speech, which was present in the public debate, also fake news and disinformation (including online disinformation) $)^{13}$ created a new kind of

\footnotetext{
${ }^{9}$ Przemysław Czarnek (former voivode of the Lublin Voivodeship; in 2019, elected as an MP, as a representative of the ruling Law and Justice Party), has described the 2018 Lublin Equality March as promoting "perversions, deviations and denaturing" and he has contributed to the incitement of violence by right-wing groups against the march participants in 2018. Also he has made public statements in relation to Ukrainians and Muslims and has framed gender as an ideology. Bart Staszewski, the leader of the Lublin Equality March, won in the civil court and Czarnek had to apologize for his words.

${ }^{10}$ In 2015, the leader of the Law and Justice party said that "migrants carry parasites and protozoa" as well as "very dangerous diseases long absent from Europe". It turned the migrant crisis into a political issue [Cienski 2015].

${ }^{11}$ On the examples of metaphors about refugees and migrants in public debate in 2015-2017, see more: Wigura, Bertram, Puchejda [2017].

${ }^{12}$ In 2017, Stanisław Piotrowicz (the key figure taking part in of the Polish reform of judiciary, former prosecutor, now a member of the Constitutional Tribunal) used this statement in relation to the Polish judges. In December 2019, the Warsaw District Court has convicted a pro-government official for violating the good name of the First President of the Supreme Court, who sued him for calling Poland's judges "ordinary thieves".

13 The High Level Expert Group on Fake News and Online Disinformation (HLEG) prefers the word "disinformation" over "fake news". The HLEG defines this term as "all forms of false, inaccurate, or misleading information designed, presented and promoted to intentionally cause public harm or for profit" [A Multi-Dimensional... 2018: 3].
} 
propaganda in the information society. Computational propaganda is disseminated in cyberspace. Samuel C. Woolley and Philip N. Howard call this new kind of propaganda "digital misinformation and manipulation". The computational propaganda describes the use of algorithms, automation, and human curation to purposefully manage and distribute misleading information over social media networks [Woolley, Howard 2019: 4]. The black market for social media manipulation tools and services is open and available both in Poland (through the Internet, e.g. via Google, Bing, Yahoo) and other countries, which is also noticed by researchers from NATO StratCom [Bay, Reynolds 2018].

Anna Mierzyńska analysed the social media accounts of selected media in Poland, including the public media accounts in 2019 (television and radio). According to the scientist, 353 tweets containing the abbreviation LGBT with the negative comments appeared on the Polish Radio's accounts. On average, one tweet with a negative comment appeared every day. There were slightly fewer of them on the Polish Television account, i.e. 275 a year. Their range was 33 million mentions (in the case of the Polish Radio - 1.5 million mentions). These numbers concerned only mentions of LGBT. In 2019, the TVP accounts were leaders as far as the number of those negative mentions is concerned. In addition, there were 178 comments on the TVP Facebook account and their range was 7.3 million [Mierzyńska 2020].

According to the European Front, the source of disinformation in the social media were primarily Polish political actors, although the content they disseminate was often convergent with pro-Kremlin disinformation. The content published by the politicians of the ruling coalition in social media was calculated to consolidate existing divisions and they most effectively used polarization and the fear management [Grabarczyk, Mazurkiewicz, Patrick 2019: 6]. For example, analysing the appearance of the topic of migration and asylum in the 2019 election campaign, from the perspective of possible disinformation, one could notice the presence of narrative schemes regarding alleged threats associated with the presence of people from Muslim countries in Western Europe. In particular, statements about a rise of crimes and rapes of European women committed by migrants or refugees, Sharia and no-go zones in some European cities were presented by some politicians running for election. In addition, using the term "LGBT ideology" by some church officials and other political actors should be considered as spreading disinformation. In the colloquial Polish language, "ideology" refers to false consciousness and someone's particular personal interest, therefore, the entwining the LGBT+ acronym with the word "ideology" was a rhetorical attempt to deprecate the postulates of the LGBT+ community in Poland. Even though these related primarily to ensuring equal rights and combating discrimination, during debates, they were fought with the imprecise but sinister slogan "LGBT ideology" [Mikulska-Jolles 2020: 3]. Among numerous hate speech cases, the following deserve to be highlighted:

- in 2019, Onet.pl revealed the existence of an organized online trolling campaign aimed to discredit Polish judges. This smear campaign was coordinated by the 
Ministry of Justice (known as the "Piebiak Gate" or the "Piebiak Scandal"). One of the professional trolls (known as "Emilia") had been regularly posting material on Twitter (from the The CasteWatch / The JusticeWatch account, in Polish: KastaWatch) about the judges whose rulings and public comments were critical of government policy (e.g. "F... off! You are bringing shame on honest judges and dishonour to Poland"). Onet's investigations reached the Supreme Court and a smear campaign against the First President of Poland's Supreme Court and the President of the Polish Judges Association "Iustitia". One of the most common Twitter accounts linked the KastaWatch account with the accounts of judges from the current National Council of the Judiciary whose status is being undermined. The persecuted judges among other former spokesman for the National Council of the Judiciary sued those judges for libel and stalking [Pankowska 2019]. The case of the KastaWatch scandal was still pending at the end of 2020 ,

- the prosecutor's office has discontinued the investigation regarding a manifestation from November 2017, when its organisers hanged photos on gallows, showing MEPs who had voted for the European Parliament's resolution regarding the rule of law in Poland. The manifestation was organised by nationalistic circles "Stop Contemporary Targowica" (among others: The All-Polish Youth [Pol.: Młodziez Wszechpolska]). The prosecutor's office argued that the manifestation was organized "in defence of national and patriotic values" (the inscription was referred to the history of the confederation of Polish and Lithuanian magnates who opposed the Constitution of 3 May 1791) and according to the prosecutor, the organizers did not break the law (after the long time over the two years of conducting investigation). In terms of moral and ethical categories, the prosecution has critically assessed the way of expressing their viewpoint. The prosecutor's office informed that the performance that had included hanging portraits of politicians on constructions imitating gallows had a symbolic character, referring to historical events from the $18^{\text {th }}$ century, portrayed in a painting by Jan Piotr Norblin and in the intention of the organizers the performance was to draw an analogy between the Targowica Confederation and the MEPs voting for the resolution. But it should be noted the inquiry was conducted into possible violence of threat against a group of people or a person due to their political views (Article 119 of the Criminal Code),

- in 2019, the prosecutor's office closed the investigation regarding fake "certificates of political death" of 11 mayors of Polish cities because, according to the prosecutor, the documents did not contain any threats and were an expression of opinion. In 2017, the All-Polish Youth prepared and published online "certificates of political death" of 11 Polish city mayors who have signed a declaration for co-operation on migration and expressed their willingness to accept refugees. Among those 11 city mayors was Paweł Adamowicz, the mayor of Gdańsk who died after being stabbed while on stage during the finale of the Great Orchestra of Christmas Charity. It should be noticed that the assailant seized a microphone and declared that he was seeking revenge against the opposition Civic Platform (the party to which Adamowicz previously belonged) for 
his imprisonment and "torture". In addition, it should be added that both Jerzy Owsiak (the founder of the Orchestra) and Adamowicz were the objects of the smear campaign on the part of the nationalist press and the public media who perceived the Orchestra as a leftist organization, and Adamowicz as the opponent of "the good change", the friend of LGBT+ community and migrants. Unfortunately, the assassination of Adamowicz revealed political polarization of the public sphere in Poland,

- every year, xenophobic phrases and far-right symbols are exposed during the Independence March on 11 November, especially since 2016 (around 60,000 people joined) organized by the far-right and nationalist groups. During the Independence March, some attendants called for "White Europe", "White Race", or "Clean Blood". There could be seen such statements as "every refugee is terrorist", "Poland for Poles", "Islam - death of white Europe" and "The whole of Poland shouts with us, kill Islam with machetes". No one has been convicted of stirring up hatred. On the other hand, the women who were sitting on the route of the March with the banners reading "Stop fascism" were convicted. They were kicked and insulted by vulgar words. The prosecutor discontinued the proceedings against the organizers of the Independence March because they were responsible for ensuring safety during the demonstration. According to the court's judgment, the purpose of the attacks against the protesting women was not to hurt them but to "show dissatisfaction",

- in 2018, shortly before the elections, the Law and Justice party released a video in which they urged the Poles to choose "safe local government" and reject the Civic Platform party which, according to the ruling party, planned to take in droves of refugees. Fictional news clips showed images of migrants rioting in ransacked Polish cities, with the voice-over describing Poland in 2020 with "enclaves of Muslim refugees" (no-go zones), a place where "sexual assaults and acts of aggression have become part of everyday life (see the video \#BezpiecznySamorzad on Twitter), - an LGBT+ ideology-free zone (Polish: Strefa wolna od ideologii LGBT+), also referred to as LGBT+ free zone (Polish: Strefa wolna od $L G B T+$ ), is a region which declared itself free of LGBT+ ideology as a result of an act passed by a Polish municipality, county or voivodeship. The declared LGBT+ ideology-free zones, although only symbolic, represent an attempt to stigmatize and exclude members of the LGBT+ community and are an expression of symbolic violence and approval of hate speech in Poland towards non-heteronormative people. As of January 2020, around 80 different LGBT+ ideology-free zone declarations have been made in Poland, including voivodeships in the south-east and central parts of the country: Małopolskie, Podkarpackie, Świętokrzyskie and Lubelskie [LGBT-Free Zones Project ${ }^{14}$ (see Figure 1).

${ }^{14}$ In December 2019, the European Parliament voted (463 to 107) in favour of condemning more than 80 such zones. The European Parliament regretted: "The fact that LGBT+ people experience bullying and harassment that begins at school and urges the Commission and the Member States to take concrete actions to end discrimination against LGBT+ people, which can lead to their being bullied, abused or isolated, in particular in educational settings" [European Parliament Resolution of 18 December 2019...]. 


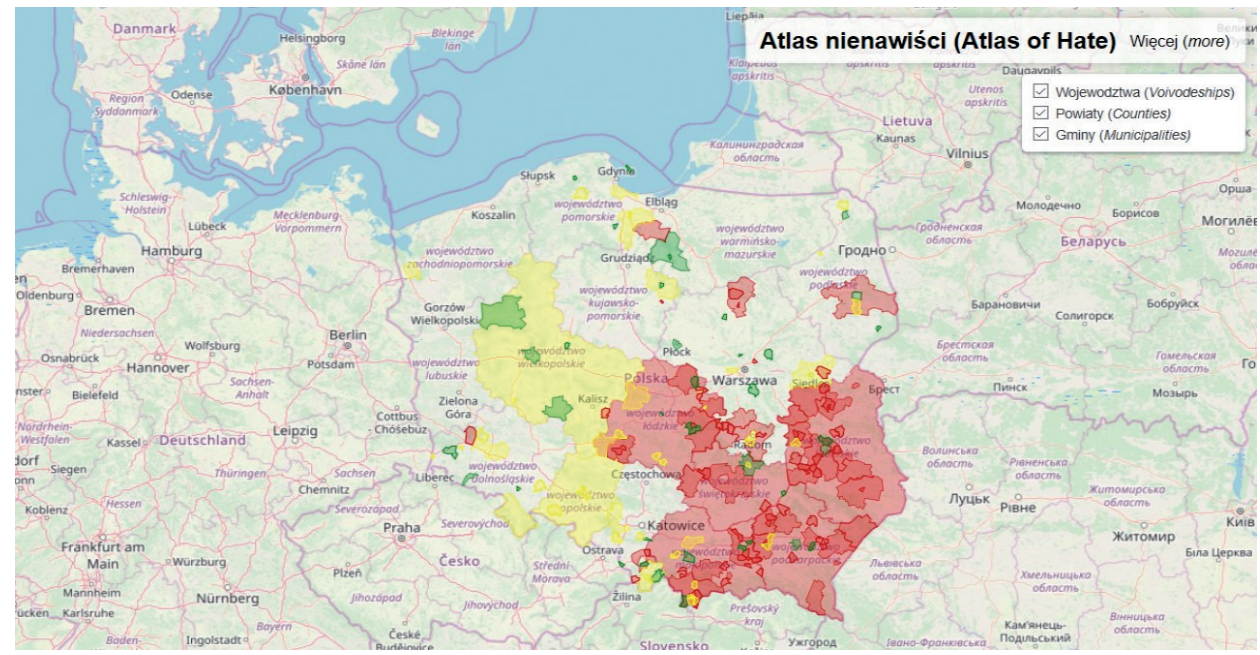

Figure 1. Map of the discriminatory resolutions of local governments against LGBT+ ideology or Regional Charters of Family Rights in Poland (2020)

Red colour means regions with adopted resolutions (or declarations), green - rejected ones and yellow - lobbing activities. Source: Atlas nienawiści [Atlas of Hate], https://atlasnienawisci.pl/ (access: 29.02.2020).

According to available statistics, since 2015, the number of cases related to Articles 119(1), 256, and 257 reported to the police has significantly increased. This increase corresponded with the rise of xenophobic and racist incidents in Poland. What is more, the number of reported cases of online hate speech has significantly increased [New... 2019]. For example, according to the National Prosecutor's Office, 1,449 proceedings for crimes committed for racist, anti-Semitic or xenophobic reasons were registered in 2017 (350 proceedings regarding Article 119 of the Criminal Code, 544 - regarding Article 256 of the Criminal Code, 536 - regarding Article 257). But the Commissioner for Human Rights in Poland and the ODIHR / OSCE noted that only $5 \%$ of hate crimes were reported to the police [Hate Crime Reporting 2019].

It should be noted that in August 2019, the Committee on the Elimination of Racial Discrimination was deeply concerned about the low percentage of offenses of hate speech and hate crimes that were reported by the public authorities, despite the recorded increase in the incidence of such crimes, and about the fact that some of the reported racially motivated crimes remained unregistered and not investigated as such. According to the Committee, the increased number of preparatory proceedings and indictments of perpetrators of racist crimes did not result in a significant increase in the number of convictions. In addition, it remains concerned about the lack of detailed information on investigations and prosecutions of, and convictions for, racist hate speech and hate crimes, especially those committed by public figures and politicians [Concluding... 2019: 3]. This lack of data which the Committee informed about should be called the "underreporting mechanism". 
Furthermore, while noting the criminalization of hate crimes and hate speech in Articles 119, 256 and 257 of the Criminal Code, the Committee was concerned also that "colour" and "descent" as grounds for inciting hatred were missing from this definition. It noticed the prevalence of racist hate speech against minority groups, in particular Muslims, Roma, Ukrainians, people of African and Asian descent, Jews and migrants, refugees and asylum-seekers. It was also concerned that leading public figures, including politicians and media officials, are frequently the source of such offensive statements or fail in their responsibility to strongly denounce hate speech [Concluding... 2019: 4]. The Committee urged the authorities to ensure effective enforcement of the laws declaring illegal parties or organizations which promote or incite racial discrimination, such as the National Movement, the National-Radical Camp, All-Polish Youth, Falanga, Szturmowcy, Niklot, the National and Social Congress, Autonomic Nationalists, Pride and Modernity Association and the local chapter of Blood and Honour [Concluding... 2019: 4].

All the incidents of hate speech listed above, as well as those unmentioned in this article, testify to the creation of a certain atmosphere of consent for the dissemination of hate speech in public debate against all the political opponents and other people who oppose or criticize the current authorities. As already noted, the public media and the organizations supporting the Law and Justice party, such as Ordo Iuris, approved the "atmosphere of consent" for the spread of the hate speech in the public debate.

\section{THE ROLE OF THE COMMISSIONER FOR HUMAN RIGHTS IN FIGHTING} DISCRIMINATION

The Commissioner for Human Rights (hereafter referred to as "the Commissioner") is the constitutional authority for legal control and protection. In his activities, the Commissioner is integral and independent from other state authorities. The Polish Commissioner (Ombudsman) operates on the basis of two legal acts, namely the Constitution of the Republic of Poland of 2 April 1997 and the Act on the Commissioner for Human Rights of 15 July 1987. The Commissioner checks the facts presented by a complainant, but may also request another supervisory body to investigate the case. The Commissioner may examine the case right away or request the case files or information about the status of the case to be delivered by any institution concerned. Having examined the case and confirmed that human and citizen rights or freedoms have been infringed, the Commissioner refers the request to the competent authority, organisation or institution whose actions led to the infringement, or to a superior authority to ensure redress for the infringement, and monitors implementation of the recommended actions. The Commissioner may lodge a last resort appeal with the Supreme Court in a penal case and may participate in constitutional complaint proceedings before the Constitutional Tribunal. The Commissioner may also exercise other powers laid down in the Commissioner for Human Rights Act (Articles 
14-16). Having examined a case, the Commissioner may demand that preparatory proceedings be instituted by a competent prosecutor in cases involving offences prosecuted ex officio on the basis of Article 14(5).

So, the mandate of the Commissioner includes: monitoring, supporting, and promoting equal treatment, carrying out independent research on the topic of discrimination, preparing and publishing reports, and making recommendations on discrimination-related issues. He is required to present information on his activities related to equal treatment, including proposals and recommendations in this area to both chambers of parliament on an annual basis. Also he is further able to act ex officio or in response to applications or complaints received from concerned individuals.

The Office of the Commissioner for Human Rights is an auxiliary unit, ensures the execution of the Commissioner's tasks laid down in the Act on the Commissioner for Human Rights. The Commissioner manages the Office with the help of three Deputy Commissioners for Human Rights. Within the Office, the Local Representatives in Gdańsk, Katowice and Wrocław, appointed by the Commissioner, are functioning. The Office includes 17 statutory organisational units, within which departments and sections operate. There were 287 employees in 2019.

The Polish Commissioner is very concerned about the scale, the scope and the dynamics of the hate speech and hate crimes phenomenon. In his speech delivered at the Third National Congress on Human Rights in December 2019, he noticed that: "The whole political and media discourse is currently swamped with personal attacks, »news of the day« coming from political parties, scandals, mutual allegations, everyday ping-pong between several political groups" [Human rights 2035:...]. In the years 2015-2020, the Polish Ombudsman kept dedicated records on complaints related to hate speech. Importantly, the Commissioner and his office additionally undertook various positive measures aimed at tackling hate speech in Poland. For example:

- maintaining contact with the National Broadcasting Council, the editorial boards of the Polish media, the Council of Media Ethics, and representatives of social media platforms and NGOs, experts and journalists,

- initiating dialogue on the need to combat hate speech in public discourse; e.g. in February 2017, the Commissioner's Office organised a debate with editorial boards focusing on the image of the Muslim community as portrayed in the press, at which a report that had been ordered by the Commissioner, entitled "The Negative Image of Muslims in the Polish Press" was launched,

- taking the initiative titled "Twenty recommendations on effective fight against hate speech" in 2019 whose purpose should be a multi-dimensional cooperation with numerous public institutions and organizations to develop a strategy on preventing hate speech at the legal, cultural, political educational level,

- taking the initiative titled " 30 examples of hate speech cases in which the prosecutor's office raises the Ombudsman's doubts" in cooperation with the Open 
Republic ${ }^{15}$ in 2019. The Ombudsman intervened, among others, in the cases of promoting racism, fascist regime and public hate speech which were discontinued by the prosecutor's office, e.g. the case of anti-migrant marches of the All-Polish Youth and the National-Radical Camp in Białystok, Warsaw, Wrocław, Hajnówka and others during which incitement to hatred, and anti-democratic symbols were presented (e.g. Celtic cross, Falanga and other fascist symbols). He also intervened on a number of occasions, e.g. public statements of hate speech made by a former Catholic priest, certificates of political death, the Independence March 2016-2018, clips titled "safe local government",

- cooperating with social media, especially with Facebook, in order to develop standards of protection against "hate speech" on their platforms, including implementation of the European Code of Conduct on countering illegal hate speech online, drafted by the European Commission in 2016,

- adopting the position of the Commissioner on the adoption by the public administration entities of declarations opposing the LGBT ideology; the Ombudsman expressed his strong opposition to these declarations and announced that he would lodge a complaint to the administrative court,

- promoting the space for debate among various stakeholders in the media environment, including social media, human rights organisations, politicians, and public authorities. For example, he set up Anti-Hate Platforms to operate at national and local levels.

Unfortunately, despite the positive efforts of the current Commissioner, including in cases of hate speech, he is often criticised and undermined by politicians of the ruling party and his Office faced a budgetary reduction. The expenditure on current operations decreased drastically - over PLN 37 million in 2014-2015 and PLN 34 million in 2016-2018 [Commissioner's budget 2020]. The Ombudsman is also sometimes undermined by the law enforcement authorities. The prosecutors interfere in court cases concerning LGBT+ persons that are dealt with by the Commissioner. Prosecutors join the proceedings, and they allegedly do so, but not to support the victims but "as a way to control what is happening or to represent the opposing party". A new trend has been noticed by the Ombudsman and other actors engaged in LGBT+ issues, all court cases in relation to the rights of LGBT+ persons that are dealt with by the office of the Ombudsman attract attention of the prosecution services [Bojarski 2018: 149].

${ }^{15}$ The Open Republic is the association which takes actions against anti-Semitism and Xenophobia. It was established in 1999 as an expression of the need to counteract xenophobic and anti-Semitic prejudice reappearing in the Polish public life, http://www.otwarta.org/en/about-association/ (access: 17.03.2020). 


\section{CONCLUSIONS}

Democracy depends on the rule of law. However, the ruling coalition treats the Polish judiciary as a mere obstacle to exercising power [Applebaum 2020]. Any person who does not share the views of the ruling coalition and performs the public functions, e.g. the President justice of the Supreme Court, the Human Rights Commissioner, the Marshal of Senate, the journalists who play their watchdog role, NGOs leaders, etc. are perceived as opponents. Since 2015, the ruling party is supported by the public media, Radio Maryja, ${ }^{16}$ independent organizations, such as the Ordo Iuris Institute, and finally by some Church representatives.

The phenomenon of racism, anti-Semitism and other examples of hatred is not new in Poland, but mainstreaming of racist, anti-Semitic, homophobic and other hateful, stigmatizing or excluding narratives should be partially attributed to the current United Right coalition. Nationalism expressed through racist, anti-Semitism, anti-Ukrainian, homophobic and Islamophobic sentiments has become the mainstream in Polish public media, including the selected far-right media, the nationalist groups' social media accounts and in the public debate. Unfortunately, Polish populist politicians use a lot of hate speech statements against the judges, refugees, LGBT+ community, migrants from Ukraine, feminists, protesting teachers or support online smear and hatred campaign for political reasons, in order to win the parliamentary elections in 2015, local elections in 2018 and, finally, to win re-election in 2019. This strategy, known as the discriminatory strategy violates the Polish Constitution and the general principles of the liberal democracy - the rule of law, human rights protection and the prohibition of discrimination.

There is a climate of acceptance of extreme nationalist ideology, and of the "atmosphere of consent" for hate speech against the enemies of the Law and Justice's reforms but also the enemies of the Polish nation. Therefore, the language of hatred, hostility and exclusion became both the weapon and strategy for populist politicians to introduce their vision of the great Polish nation. The mechanism of the hate speech carousel and the phenomenon of "weaponization of information" used against anyone who is a public critic of government are watched in Poland. Thus, the United Right used discriminatory legalism in 2015-2020.

The Human Rights Commissioner, NGOs, some journalists and private media try to combat hate speech, educate and promote high standards of pluralism and open the public debate with respect for opponents. The Commissioner is the only institution who tries to combat hate speech effectively but he is regularly criticized and discredited for these actions by the ruling party politicians. He monitors hate

${ }^{16}$ The radio station is headed by Father Tadeusz Rydzyk and its programme consists of prayers, discussions and polemics. Radio Maryja can be heard both in Poland and abroad. The radio station and the television station, TV Trwam, contributed to the Law and Justice party's victories in presidential and parliamentary elections in 2005 and 2015. Radio Maria and TV Trwam are criticized for spreading anti-Semitic views, Holocaust denial and hate speech while ignoring complaints. 
speech, educates, intervenes in the cases discontinued by the prosecutor's office, cooperates with experts and organizations that deal with verbal violence.

At the time of submitting the article for printing, the 5-year term of the current Commissioner for Human Rights, Adam Bodnar, expired (on 9 September 2020). The Parliament did not select a new person for this position yet. It may be a problem because the Senate belongs to the opposition and the selection of candidate by the Sejm is made with the consent of the Senate. Thus, following Article 3.6 of the Law on the Commissioner, Bodnar stays in the office until the appointment of the new Commissioner for Human Rights. However, a group of MPs demands the Constitutional Court to delete this legal basis, leaving the office without its head. It may be another institution in the future, the head of which will be a person whose appointment could give rise to constitutional doubts.

\section{BIBLIOGRAPHY}

A Multi-Dimensional Approach to Disinformation. Report of the Independent High Level Group on Fake News and Online Disinformation. 2018. The Digital Single Market, https://ec.europa.eu/digital-single-market/en/news/final-report-high-level-expert-group-fake-news-and-online-disinformation (access: 21.11.2020).

Act of Civil Code of 23 April 1964 (Journal of Laws of 2019, items 1145, 1495).

Act of the Commissioner for Human Rights of 15 July 1987 (Journal of Laws of 2014, item 1648).

Act of Criminal Code of 6 June 1997 (Journal of Laws of 2019, items 1950, 2128).

Applebaum, A. 2020. The Disturbing Campaign Against Poland's Judges, "The Atlantic", https://www. theatlantic.com/ideas/archive/2020/01/disturbing-campaign-against-polish-judges/605623/ (access: 14.03.2020).

Atlas nienawiści, https://atlasnienawisci.pl/ (access: 29.02.2020).

Bay, S., Reynolds, A. 2018. The Black Market for Social Media Manipulation, NATO StratCom COE, Riga.

\#BezpiecznySamorzad on Twitter. 2018, https://twitter.com/pisorgpl/status/1052530980190334977 (access: 18.03.2020).

Bojarski, Ł. 2017. Country Report Non Discrimination. Poland, European Commission, https://www. equalitylaw.eu/downloads/4472-poland-country-report-non-discrimination-2017-pdf-2-15-mb (access: 21.11.2020).

Cambridge Dictionary, https://dictionary.cambridge.org/pl/dictionary/english/smear-campaign (access: 20.04.2020).

Cienski, J. 2015. Migrants carry 'parasites and protozoa', warns Polish opposition leader, "Politico", https://www.politico.eu/article/migrants-asylum-poland-kaczynski-election/ (access: 22.02.2020).

Commissioner's Budget. 2020. The Commissioner for Human Rights, https://www.rpo.gov.p1/p1/content/ budzet-rpo-vii-kadencji-informacja (access: 17.03.2020).

Concluding observations on the combined twenty-second to twenty-fourth periodic reports of Poland. 2019. Committee on the Elimination of Racial Discrimination (CERD), https://tbinternet.ohchr.org/Treaties/ CERD/Shared\%20Documents/POL/CERD_C_POL_CO_22-24_36935_E.pdf (access: 20.02.2020).

Constitution of the Republic of Poland of 2 of April 1997 (Journal of Laws of 2009, No. 114 item 1648).

Convention for the Protection of Human Rights and Fundamental Freedom of 4 November 1950 (Journal of Laws of 1993, No. 61 item. 284).

Dziemidok-Olszewska, B., Sokół, W. 2012. Encyklopedia politologii, t. 2: Instytucje i systemy polityczne, Wolters Kluwer Polska. 
Economic Intelligence Unit (EIU). 2020. Poland in Brief, http://country.eiu.com/poland (access: 18.03.2020). European Commission for Democracy Through Law. Poland - Urgent Joint Opinion on the amendments to the Law on organisation on the Common Courts, the Law on the Supreme Court and other Laws, Opinion No. 977/2019, Venice Commission, https://www.venice.coe.int/webforms/documents/default. aspx?pdf=CDL-PI(2020)002-e\&lang=fr (access: 18.02.2020).

European Commission, Rule of Law Framework, https:/ec.europa.eu/info/policies/justice-and-fundamental-rights/upholding-rule-law/rule-law/rule-law-framework_en (access: 18.02.2020).

European Democracy Index. 2019. A year of democratic setbacks and popular protest, The Economic Intelligence Unit, http://www.eiu.com/ (access: 03.03.2020).

European Parliament Resolution of 18 December 2019 on public discrimination and hate speech against LGBT+ people including LGBT free zones. 2019/2933 (RSP), European Parliament, https://www. europarl.europa.eu/doceo/document/TA-9-2019-0101 EN.html (access: 21.02.2020).

Everything you need to know about the rule of law in Poland. 2016. Rule of Law, https://ruleoflaw.pl/ (access: 21.02.2020).

Freedom House. 2018. Freedom in the World 2018. Democracy in Crisis, https://freedomhouse.org/report/ freedom-world/freedom-world-2018 (access: 20.02.2020).

Grabarczyk, J., Mazurkiewicz, M., Patrick, J. 2019. Dezinformacja i propaganda w polskim internecie w trakcie kampanii wyborczej 2019, Front Europejski, Warszawa, www.fronteuropejski.pl (access: 03.03.2020).

Guide on Article 17 of the European Convention on Human Rights. Prohibition of abuse of rights. 2019. The European Court of Human Rights, https://www.echr.coe.int/Documents/Guide_Art_17_ENG. pdf (access: 25.04.2020).

Hate Crime Reporting. 2019, https://hatecrime.osce.org/poland (access: 22.04.2020).

Human rights 2035: Five challenges and five signposts. Speech delivered by the Commissioner at the third National Congress on Human Rights. 2019. The Commissioner of Human Rights, https://www.rpo. gov.pl/en/content/human-rights-2035-five-challenges-and-five-signposts-speech-delivered-commissioner-third-national (access: 22.03.2020).

International Covenant on Civil and Political Rights of 16 December 1966 (Journal of Laws of 1977, No. 38 item 167).

Lacey, N. 2019. Populism and the Rule of Law, "Annual Review of Law and Social Science", vol. 15, pp. 79-96, DOI: https://doi.org/10.1146/annurev-lawsocsci-101518-042919.

LGBT-Free Zones Project, https://lgbtfreezones.pl/ (access: 29.02.2020).

Loewenstein, K. 1937. Militant Democracy and Fundamental Rights, "The American Political Science Review", vol. 31(3), pp. 417-432, DOI: https://doi.org/10.2307/1948164.

Łaciak, B., Segeš Frelak, J. 2018. The Wages of Fear Attitudes Refugees and Migrants in Poland, Institutes of Public Affairs, European Programme, Warsaw European Commission, https://ec.europa.eu/ migrant-integration/librarydoc/the-wages-of-fear-attitudes-towards-refugees-and-migrants-in-poland (access: 03.03.2020).

Matczak, M. 2019. Poland's Rule of Law Crisis: Some Thoughts, "Hague Journal Rule of Law", vol. 11, DOI: https://doi.org/10.1007/s40803-019-00117-y.

Mierzyńska, A. 2020. Pełzające zło homoterroru. 12 miesięcy siania nienawiści do osób LGBT przez media publiczne, https://oko.press/pelznace-zlo-homoterroru/ (access: 20.03.2020).

Mikulska-Jolles, A. 2018. Migranci, uchodźcy i ksenofobia w kampanii wyborczej 2018-raport z monitoringu, Helsińska Fundacja Praw Człowieka, Warszawa, http://www.hfhr.pl/migranci-uchodzcy-i-ksenofobia-w-kampanii-wyborczej-2018-raport-z-monitoringu/ (access: 22.02.2020).

Mikulska-Jolles, A. 2020. Fake newsy i dezinformacja w kampaniach wyborczych w Polsce w 2019 r., Helsińska Fundacja Praw Człowieka, Warszawa, http://www.hfhr.pl/fake-newsy-i-dezinformacja-wkampaniach-wyborczych-w-polsce-w-2019-r-raport-z-obserwacji/ (access: 03.03.2020).

Müller, J.-W. 2016. What is Populism, University of Pennsylvania Press, Philadelphia. 
New study reveals scale of underreporting of hate incidents in Poland. 2019. Hate Crime Reporting, https:// hatecrime.osce.org/infocus/new-study-reveals-scale-underreporting-hate-incidents-poland (access: 20.03.2020).

Office for Foreigners. 2018, https://udsc.gov.pl/en/statystyki/raporty-okresowe/raport-roczny-ochrona-miedzynarodowa/2017-2/ (access: 20.03.2020).

Pankowska, M. 2019. Smear campaign coordinated by the Ministry of Justice, aimed to discredit Polish judges, discovered, https://oko.press/why-did-the-polish-deputy-minister-of-justice-resign-everythingyou-need-to-know-about-the-piebiak-scandal/ (access: 22.02.2020).

Parliamentary Assembly of the Council of Europe. 2019. The functioning of democratic institutions in Poland, http://www.assembly.coe.int/LifeRay/MON/Pdf/TextesProvisoires/2019/20191213-PolandInstitutions-EN.pdf (access: 10.05.2020).

Public Opinion Research Centre. 2018. Stosunek Polaków i Czechów do przyjmowania uchodźców, no. 87, https://www.cbos.pl/SPISKOM.POL/2018/K_087_18.PDF (access: 15.04.2020).

Recommendation No. R (97) 20 of the Committee of Ministers to Member States on „Hate Speech” adopted by the Committee of Ministers on 30 October 1997. The Council of Europe, https://rm.coe.in$\mathrm{t} / 1680505 \mathrm{~d} 5 \mathrm{~b}$ (access: 15.04.2020).

Sadurski, W. 2018. How Democracy Dies (in Poland): A Case Study of Anti-Constitutional Populist Backsliding, "Sydney Law School Research Paper" no. 18/01, DOI: http://dx.doi.org/10.2139/ssrn.3103491 (access: 20.04.2020).

The Open Republic, http://www.otwarta.org/en/about-association/ (access: 17.03.2020).

Timbro Authoritarian Populism Index. 2019, https://populismindex.com/wp-content/uploads/2019/02/ TAP2019C.pdf (access: 20.04.2020).

Torre de 1a, C. 2017. Hugo Chávez and the diffusion of Bolivarianism, "Democratization", vol. 24(7), pp.1271-1288, DOI: https://doi.org/10.1080/13510347.2017.1307825.

Tucker, J.A., Theocharis, Y., Roberts, M.E., Barberá, P. 2017. From liberation to turmoil: Social media and democracy, "Journal of Democracy", vol. 28, pp. 46-59.

Weyland, K. 2013. Latin America's Authoritarian Drift: The Threat from the Populist Left, "Journal of Democracy" vol. 24(3), pp. 18-32.

Wigura, K., Bertram, Ł., Puchejda, A. 2017. The Negative Portrayal of Muslims in the Polish Press. A Report by the Kultura Liberalna's Public Debate Observatory, The Human Rights Commissioner, Warsaw, https://www.rpo.gov.pl/sites/default/files/The_Negative_Portrayal_of_Muslims_in_the_Polish_Press. pdf (access: 20.04.2020).

Winiewski, M., Hansen, K., Bilewicz, M. et al. 2016. Contempt Speech, Hate Speech. Report from Research on Verbal Violence Against Minority Groups. Stefan Batory Foundation, Warsaw, http://www. ngofund.org.pl/wp-content/uploads/2017/03/ContemptSpeechHateSpeech.pdf (access: 03.03.2020).

Woolley, S.C., Howard, P.N. 2019. Computational Propaganda. Political Parties, Politicians, and Political Manipulation on Social Media, Oxford Scholarship Online, Oxford.

\section{BIOGRAPHY}

Agnieszka Elżbieta Demczuk, a PhD, lawyer and political scientist, Assistant Professor at the Department of Political Systems and Human Rights, the head of The Disinformation and Propaganda Research Team at the Institute of Political Sciences and Administration, University of Maria Curie-Skłodowska in Lublin. E-mail: ademczuk@hektor.umcs.lublin.pl 